\title{
Editorial
}

\section{Lipid Rafts and Amyloidogenesis}

Lipid rafts are the membrane microdomains enriched in cholesterol and sphingolipids, which play important roles in such cellular processes as protein sorting and signal transduction. Lipid rafts have recently received significant attention as they have been shown to be important regions for the generation and accumulation of $\beta$-amyloid peptide $(A \beta)$, the main culprit in the pathogenesis of Alzheimer's disease. For instance, the proteases responsible for the production of A $\beta$ are localized to lipid rafts, and rafts appear to be involved in the pathological aggregation of $A \beta$. Thus, the relationship between lipid rafts and amyloidogenesis is considered a critical issue to be investigated. In addition, modulation of lipid rafts is an interesting issue in biological sciences. In this special issue, the first two articles by Wataru Araki and Madepalli K. Lakshmana focus on the relation between lipid rafts and the mechanisms of $\mathrm{A} \beta$ generation, and the third article by Gunter P. Eckert mainly deals with the manipulation of lipid rafts in neuronal cells. I hope that this special issue provides informative unique collection of minireviews which highlight the significance of lipid rafts in amyloidogenesis.

\section{Wataru Araki}

(Guest Editor)

Department of Demyelinating Disease and Aging National Institute of Neuroscience, NCNP

Kodaira, Tokyo 187-8502

Japan

E-mail: araki@ncnp.go.jp

(C) Wataru Araki; Licensee Bentham Open.

This is an open access article licensed under the terms of the Creative Commons Attribution Non-Commercial License (http://creativecommons.org/licenses/bync/3.0/), which permits unrestricted, non-commercial use, distribution and reproduction in any medium, provided the work is properly cited. 